Article

\title{
Use of Thermally Modified Jarosite for the Removal of Hexavalent Chromium by Adsorption
}

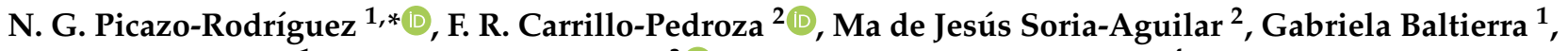 \\ Gregorio González ${ }^{1}$, A. Martinez-Luevanos ${ }^{3}{ }^{-1}$ and Isaías Almaguer Guzmán ${ }^{4}$ \\ 1 Instituto Tecnológico Superior de Monclova, Tecnológico Nacional de México, Monclova 25701, Mexico; \\ gabriela.bc@monclova.tecnm.mx (G.B.); gregorio.gz@monclova.tecnm.mx (G.G.) \\ 2 Facultad de Metalurgia, Universidad Autónoma de Coahuila, Monclova 25710, Mexico; \\ raul.carrillo@uadec.edu.mx (F.R.C.-P.); mjsoriaa@yahoo.com.mx (M.d.J.S.-A.) \\ 3 Facultad de Ciencias Químicas, Universidad Autónoma de Coahuila, Saltillo 25280, Mexico; \\ am115902@uadec.edu.mx \\ 4 Peñoles, CIDT-SEPSA, Torreon 27220, Mexico; isaias_almaguer@penoles.com.mx \\ * Correspondence: nallely_pikzo@hotmail.com
}

Citation: Picazo-Rodríguez, N.G.; Carrillo-Pedroza, F.R.; Soria-Aguilar, M.d.J.; Baltierra, G.; González, G.; Martinez-Luevanos, A.; Almaguer Guzmán, I. Use of Thermally Modified Jarosite for the Removal of Hexavalent Chromium by Adsorption. Crystals 2022, 12, 80 . https://doi.org/10.3390/ cryst12010080

Academic Editor: Shujun Zhang

Received: 2 December 2021

Accepted: 30 December 2021

Published: 7 January 2022

Publisher's Note: MDPI stays neutral with regard to jurisdictional claims in published maps and institutional affiliations.

Copyright: (C) 2022 by the authors. Licensee MDPI, Basel, Switzerland. This article is an open access article distributed under the terms and conditions of the Creative Commons Attribution (CC BY) license (https:// creativecommons.org/licenses/by/ $4.0 /)$.

\begin{abstract}
Jarosites are residues generated during the purification of zinc and are composed mainly of iron sulfates $\left((\mathrm{Na}, \mathrm{K}) \mathrm{Fe}_{3}\left(\mathrm{SO}_{4}\right)_{2}(\mathrm{OH})_{6}\right)$. Due to the large volume of jarosite generated during the process, these residues tend to be deposited in large land areas and are not used. In the present work, jarosite was used without heat treatment (JST) as an adsorbent of hexavalent chromium contained in a sample of wastewater from a chrome plating industry under the following conditions: $\mathrm{C}_{0}=200 \mathrm{mg} / \mathrm{L}$ of $\mathrm{Cr}, \mathrm{T}=25^{\circ} \mathrm{C}$, and $\mathrm{pH}=3$. It was only possible to remove $34 \%$ of $\mathrm{Cr}(\mathrm{VI})$. Subsequently, a thermal treatment of a jarosite sample (JTT) was carried out at $600{ }^{\circ} \mathrm{C}$. The heat-treated sample was later used as an adsorbent in the same conditions as those for JST. The maximum chromium removal was $53 \%$, and the adsorption capacity was $10.99 \mathrm{mg} / \mathrm{g}$. The experimental data were fitted to the Langmuir model and to the pseudo-second-order kinetic model. It was determined that the adsorption process involved electrostatic attractions between the surface of the positively charged adsorbent and the chromium anions contained in industrial wastewater.
\end{abstract}

Keywords: jarosite; adsorption; hexavalent chromium

\section{Introduction}

The electrolytic process to obtain zinc is one of the most widely used hydrometallurgical processes. It consists of subjecting zinc to roasting and subsequently leaching it in a sulfuric acid solution. However, in addition to zinc, the solution contains iron, which in the subsequent process (zinc electrolysis), can cause short circuits. For this reason, to eliminate iron, the solution is neutralized with calcine, thus obtaining jarosite as a precipitate [1-3]. The precipitate is generated in large quantities and contains mainly iron sulfates and jarosite $\left((\mathrm{Na}, \mathrm{K}) \mathrm{Fe}_{3}\left(\mathrm{SO}_{4}\right)_{2}(\mathrm{OH})_{6}\right.$. Due to the large volumes of jarosite generated during the process, these residues are commonly deposited in large land areas [4-7].

Some researchers have proposed to recover the valuable elements contained in jarosite [8,9], and others have proposed to use jarosite in various applications, among which are nanoparticle synthesis [10], as a catalytic material for the precipitation of iron in the process of obtaining zinc [11], pigment elaboration [12], construction of road embankments [13]. Xiaoa et al. [14] synthesized a biogenic jarosite in the presence of Acidithiobacillus ferrooxidans (A. ferrooxidans), which they used as an adsorbent of hexavalent chromium.

$\mathrm{Cr}$ (VI) is one of the heavy metals most harmful to health and the environment, widely used in the metallurgical, refractory, and chemical industries for the production of chromium alloys, chrome plating, pigments, tanning, and the synthesis of oxidizing agents and corrosion inhibitors; therefore, it can be present in the effluents from these 
industries. The tolerable levels of hexavalent chromium in surface water and drinking water are $0.1 \mathrm{mg} / \mathrm{L}$ and $0.05 \mathrm{mg} / \mathrm{L}$, respectively [15].

Various techniques such as precipitation, adsorption, ion exchange, and electrocoagulation have been used for the treatment of wastewater containing $\mathrm{Cr}(\mathrm{VI})$; however, the adsorption process is flexible in design and operation and, in most cases, offers high removal efficiency [15-19].

Some adsorbents have been applied in the removal of hexavalent chromium, such as activated carbon and nanoparticles synthesized from iron oxides [20-23] and have given good results, but in addition to being expensive, they are difficult to use on an industrial scale. In recent years, the application of low-cost adsorbent materials such as natural minerals (sand, coal, moss, peat etc.), agricultural wastes (fruits and vegetables peels, nuts, shells, pulps, stones, etc.), forests wastes (barks, roots, leaves, and sawdust), and industrials wastes (sludge, furnace slag, fly ash, and waste smelters) has been developed [24,25].

The application of jarosite as an adsorbent of metal ions is promising, because it is a cheap and abundant by-product and, in particular, it would be a good option for the adsorption of metal ions present in polluted waters. Jarosites can be structurally modified through thermal and hydrothermal treatments, which can activate it and enhance its natural properties as an adsorbent [26-31].

The present study was limited to evaluating the capacity of jarosite with and without heat treatment as a low-cost adsorbent for hexavalent chromium present in real industrial waters, with the aim applying it as an adsorbent material in the treatment of industrial effluents. The tests were carried out at a $\mathrm{pH} 3$, which is normally found in wastewater derived from the chrome plating process. Increasing the $\mathrm{pH}$ in an industrial process implies the additional consumption of reagents which generates economic and negative environmental impacts. On the other hand, hexavalent chromium, which is the most dangerous chromium species, is found in water at acidic $\mathrm{pH}$. In the present work, the study of the adsorption mechanisms of hexavalent chromium contained in a sample of industrial wastewater from a chrome plating process was carried out, using jarosites thermally treated at $600{ }^{\circ} \mathrm{C}(\mathrm{JTT})$ as a low-cost adsorbent material.

\section{Materials and Methods}

In the present work, a sample of jarosite, generated as a residue in a hydrometallurgical process to obtain zinc, was evaluated as an adsorbent material. It was decided to use both the residue generated directly from the process (JST) and a sample thereof heat-treated at $600{ }^{\circ} \mathrm{C}$ in a muffle for 1 hour (JTT).

A wastewater solution from the metal coating industry was used in the adsorption tests, containing $200 \mathrm{mg} / \mathrm{L}$ of chromium (as chromic acid), $\mathrm{Fe}, 25 \mathrm{mg} / \mathrm{L}$, and $\mathrm{SO}_{4}^{2-}$, $130 \mathrm{mg} / \mathrm{L}$, at $\mathrm{pH}=3$. At this $\mathrm{pH}$, hexavalent $\mathrm{Cr}$ is present as $\mathrm{HCrO}_{4}^{-}$ions [21,32], as shown in Figure 1 which reports a species distribution diagram with the actual concentrations of $\mathrm{HCrO}_{4}^{-}$and $\mathrm{Fe}^{2+}$.

Batch tests were performed to remove chromium from electroplating effluent solutions. The batch experiments were carried out in $100 \mathrm{~mL}$ beakers. The adsorption tests were carried out using a specific amount of jarosites without heat treatment (JST) (in a range of 0 to $10 \mathrm{~g}$ ) and subsequently repeated with jarosite treated at $600{ }^{\circ} \mathrm{C}(\mathrm{JTT})$. The adsorbent materials were added to $100 \mathrm{~mL}$ of aqueous $\mathrm{Cr}(\mathrm{VI})$ solution and then stirred for a certain period of time at $25^{\circ} \mathrm{C}$. The resulting solution was then filtered using a filter paper. Chemical analysis of the solutions was performed by atomic absorption spectroscopy (AAS, Perkin Elmer 3100) (PerkinElmer, Waltham, MA, USA).

The amount of $\mathrm{Cr}(\mathrm{VI})$ adsorbed by jarosite and the percentage removal of $\mathrm{Cr}$ (VI) were calculated using Equations (1) and (2), respectively:

$$
\mathrm{qe}=\frac{\left(\mathrm{C}_{0}-\mathrm{Ce}\right) \mathrm{V}}{\mathrm{W}}
$$




$$
\mathrm{Cr}_{\text {adsorbed }}, \%=\frac{\left(\mathrm{C}_{\mathrm{i}}-\mathrm{C}_{0}\right)}{\mathrm{C}_{\mathrm{i}}} * 100
$$

where, qe is the adsorption capacity in $\mathrm{mg} / \mathrm{g}, \mathrm{C}_{\mathrm{i}}, \mathrm{C}_{0}$, and $\mathrm{Ce}$ are the initial, outlet, and equilibrium concentration of $\mathrm{Cr}(\mathrm{VI})$ in $\mathrm{mg} / \mathrm{L}, \mathrm{V}$ is the volume of $\mathrm{Cr}(\mathrm{VI})$ solution in $\mathrm{mL}$, and $\mathrm{W}$ is the total amount of adsorbent in $\mathrm{g}$.

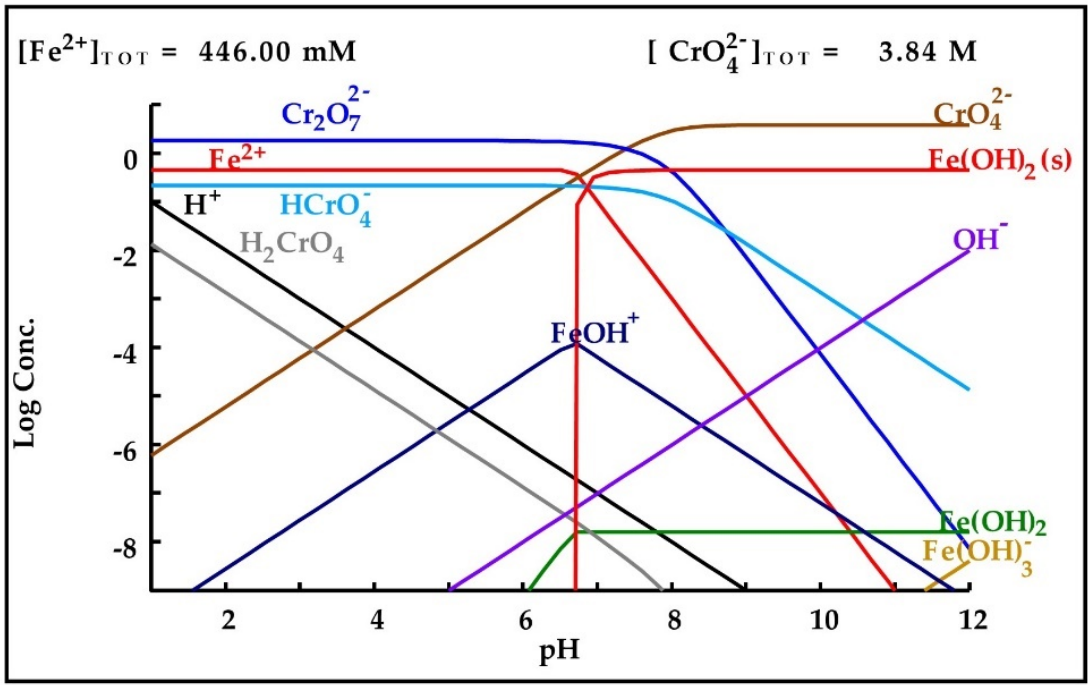

Figure 1. Species distribution diagram calculated by the software Medusa for the system concentrations of $\mathrm{HCrO}_{4}^{-}$and $\mathrm{Fe}^{2+}$.

It is important to emphasize that this research sough to determine if jarosite can be a good option for a low-cost adsorbent in industrial wastewater treatment processes; therefore, in this study, as a first approach, we carried out tests at room temperature $\left(25^{\circ} \mathrm{C}\right)$, which is the preferred temperature for industrial processes, mainly for its economic and environmental benefits.

\section{Jarosite Characterization}

The chemical composition of JST and JTT was determined by an X-ray fluorescence spectrometer (Panalytical model Epsylon) (Panalytical, Malvern, Worcestershire, UK). The results are shown in Table 1.

Table 1. Chemical composition (\%) of the JTT sample.

\begin{tabular}{ccccccc}
\hline Sample & $\mathbf{\% F e}$ & $\mathbf{\% S}^{\circ}$ & $\mathbf{\% Z n}$ & $\mathbf{\% S i}$ & $\mathbf{\% C a}$ & $\mathbf{\% P b}$ \\
\hline JST & 43.74 & 7.364 & 12.85 & 2.96 & 2.604 & 2.606 \\
\hline JTT & 46.02 & 7.46 & 13.56 & 3.107 & 2.79 & 2.57 \\
\hline
\end{tabular}

The determination of the phases presents in JST and JTT was carried out by X-ray diffraction in a Bruker D8 diffractometer. Figure 2 shows the jarosite diffraction patterns before and after heat treatment.

Table 2 shows the mineralogical reconstruction of samples of JST and JTT, which was determined by X-ray diffraction and chemical analysis, using the HSC 8.0 software (D8, Bruker, Ettlingen, Karlsruhe, Germany) in the Species Converter module.

Table 2. Iron phases distribution (\%) in JTT.

\begin{tabular}{|c|c|c|c|c|c|c|c|}
\hline Sample & $\begin{array}{c}\text { Jarosite } \\
\left(\mathrm{Fe}_{3}^{3+}\left(\mathrm{SO}_{4}\right)_{2}(\mathrm{OH})_{6}\right.\end{array}$ & Hematite $\left(\mathrm{Fe}_{2} \mathrm{O}_{3}\right)$ & Magnetite $\left(\mathrm{Fe}_{3} \mathrm{O}_{4}\right)$ & Franklinite $\left(\mathrm{ZnFe}_{2} \mathrm{O}_{4}\right)$ & $\begin{array}{c}\text { Sphalerite } \\
\text { (ZnS) }\end{array}$ & Zinc Oxide ( $\mathrm{ZnO})$ & Others \\
\hline JST & 52 & & 13 & & 7.5 & & \\
\hline JTT & & 47 & 20 & 23 & & 6.5 & 3.5 \\
\hline
\end{tabular}


(a)

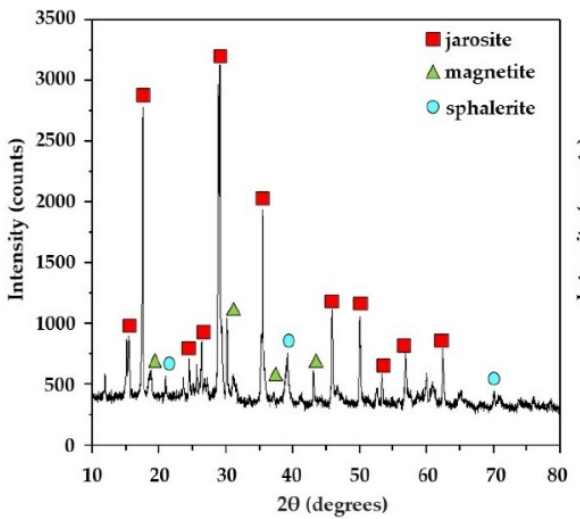

(b)

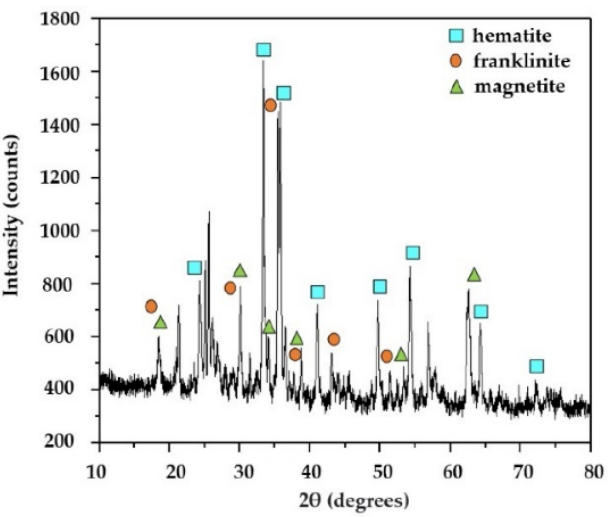

Figure 2. Diffraction patterns of samples of (a) JST and (b) JTT.

Originally, before being heat-treated, the waste (JST) consisted of $52 \%$ jarosite $\left(\mathrm{Fe}_{3}^{3+}\left(\mathrm{SO}_{4}\right)_{2}(\mathrm{OH})_{6}\right.$; after heat treatment, jarosite decomposed into different species of iron (JTT), as shown in Table 2. As can be seen in this table, JTT was composed mostly of hematite $\left(47 \%, \mathrm{Fe}_{2} \mathrm{O}_{3}\right)$ and to a lesser extent of other iron oxides such as magnetite $\left(\mathrm{Fe}_{3} \mathrm{O}_{4}\right)$ and Franklinite $\left(\mathrm{ZnFe}_{2} \mathrm{O}_{4}\right)$, as reported by Ristic et al. [28], who performed thermal decomposition of a synthetic ammonium jarosite sample at $600{ }^{\circ} \mathrm{C}$ and found that the treated sample was composed mostly of hematite. It should be noted that iron oxides are known for their high capacity to adsorb certain metals, among which, the most common found in nature are magnetite $\left(\mathrm{Fe}_{3} \mathrm{O}_{4}\right.$ ferric oxide $\left(\mathrm{Fe}_{2} \mathrm{O}_{3}\right)$, maghemite $\left(\gamma-\mathrm{Fe}_{2} \mathrm{O}_{3}\right)$, hematite $\left(\alpha-\mathrm{Fe}_{2} \mathrm{O}_{3}\right)$, and goethite $(\mathrm{FeOOH})[33,34]$.

The particle size of the JTT sample, given as $\mathrm{D}_{90}(90 \%$ of the particles passed or havd a size smaller that the corresponding mesh) was $100 \mu \mathrm{m}$.

The specific surface area of JST and JTT was determined with the classic BET method (the Brunauer-Emmett-Teller isotherm) (Quantachrome instruments, Boynton Beach, FL, USA). The point of zero charge was determined as follows:

(a) $15 \mathrm{~mL}$ of deionized water was placed in $50 \mathrm{~mL}$ tubes, and the initial $\mathrm{pH}$ was measured.

(b) Subsequently, $0.05 \mathrm{~g}$ of the JST and JTT samples was added to each tube.

(c) The tubes with the samples were then partially submerged in a bath at a constant temperature of $25{ }^{\circ} \mathrm{C}$ and shaken manually 4 times a day (in total, the test was developed in $48 \mathrm{~h}$ ).

(d) The $\mathrm{pH}$ of the suspension was measured after $12 \mathrm{~h}$, and the addition of $0.5 \mathrm{~g}$ of sample was continued sequentially every $12 \mathrm{~h}$, with $\mathrm{pH}$ measurements until reaching the equilibrium condition; the measurement was carried out in an inert atmosphere. The asymptotic $\mathrm{pH}$ condition that was reached after several sample additions corresponded to the point of zero charge.

Table 3 shows the results of the surface area and point of zero charge.

Table 3. Surface area and point of zero charge of JST and JTT.

\begin{tabular}{ccc}
\hline Sample & $\begin{array}{c}\text { Surface Area } \\
\left(\mathbf{m}^{2} \cdot \mathbf{g}^{-\mathbf{1}}\right)\end{array}$ & $\begin{array}{c}\text { Point of Zero } \\
\text { Charge (pzc) }\end{array}$ \\
\hline JST & 11.37 & 8.17 \\
\hline JTT & 11.70 & 6.81 \\
\hline
\end{tabular}

\section{Results and Discussion}

\subsection{Effect of Adsorbent Dosage}

The adsorbent dose was studied. This is an important variable to analyze, since it indicates from an economic point of view how viable the process is, in addition to indicating the degree of removal of chromium. 
To analyze the effect of the adsorbent dose, chromium adsorption tests were carried out. Different amounts of JST and JTT were used in the range of $1-10 \mathrm{~g}$, at $\mathrm{T}=25{ }^{\circ} \mathrm{C}$ (this is the temperature of the solution during the chrome plating process), with a contact time of $10 \mathrm{~min}$ and with a fixed initial $\mathrm{Cr}$ (VI) concentration (C0) of $200 \mathrm{mg} / \mathrm{L}$; the $\mathrm{pH}$ was adjusted to 3 using nitric acid. In Figure 3, it is shown how the removal of chromium increased from 30 to $34 \%$ when we increased the amount of adsorbent from 1 to $2.5 \mathrm{~g}$. Increasing the dose of the adsorbent above $2.5 \mathrm{~g}$ did not have a significant effect on the removal of chromium. However, with JTT, the removal of chromium increased from 50 to 53\% when we increased the amount of adsorbent from 1 to $2.5 \mathrm{~g}$.

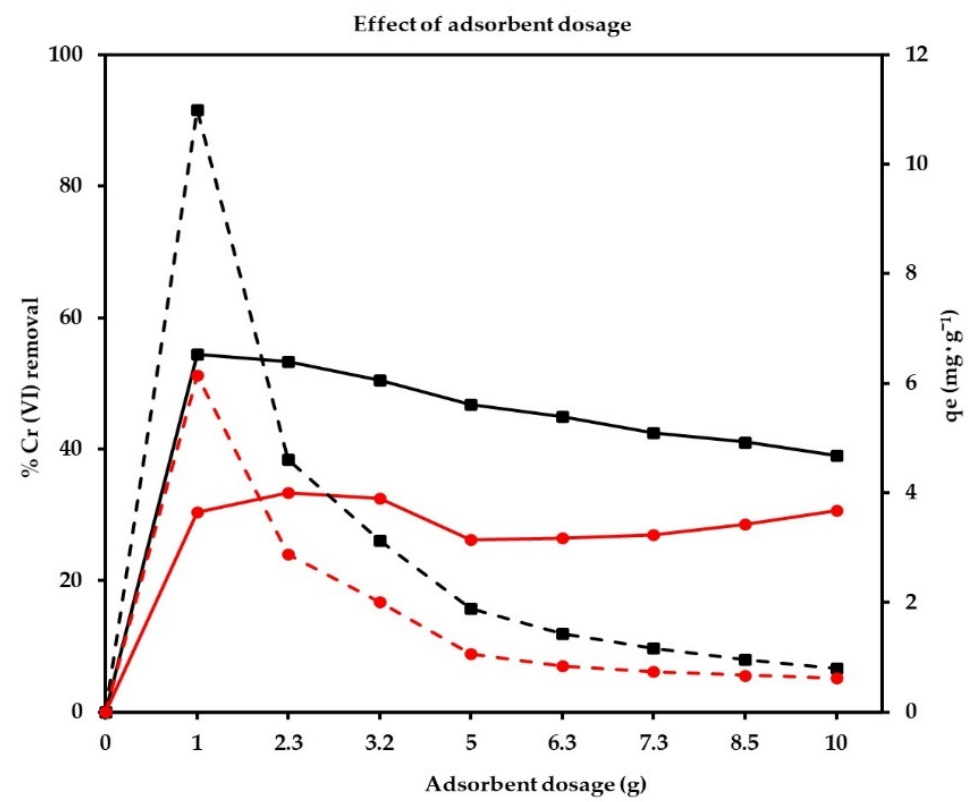

Figure 3. Effect of adsorbent dose on equilibrium adsorption capacity and removal efficiency $\left(\mathrm{C}_{0}=200 \mathrm{mg} / \mathrm{L}\right.$, temperature $=25{ }^{\circ} \mathrm{C}$, and $\left.\mathrm{pH}=3\right)$. The red lines (solid and dotted) represent the removal of $\mathrm{Cr}$ (VI) with JST and the adsorption capacity in the tests where this material was used. The black lines (solid and dotted) represent the removal of $\mathrm{Cr}(\mathrm{VI})$ with JTT and the adsorption capacity in the tests where this material was used.

The drop in $\mathrm{Cr}$ (VI) adsorption capacity in both cases was basically due to the presence of unsaturated sites during the adsorption process. In the case of the wastewater solution, the optimal $\mathrm{Cr}(\mathrm{VI})$ removal values and the adsorption capacity were $53 \%$ and $10.99 \mathrm{mg} / \mathrm{g}$, respectively, for $1 \mathrm{~g}$ of the adsorbent JTT; therefore, we observed that heat treatment had a significant effect on the removal of chromium. Based on the above, the rest of the study was focused on the JTT adsorbent.

In the present work, the $\mathrm{pH}$ of the adsorption tests was kept at a value of 3 , as mentioned above. The JTT adsorbent consists of $90 \%$ iron oxides. In accordance with Cornell and Schwertmann, iron minerals usually exhibit the so-called points of zero charge at neutral $\mathrm{pH}$ and therefore are often used as anion and cation adsorbents. The researchers mentioned that the values of isoelectric point (iep) and point of zero charge (pzc) for natural hematite are 7.0 and 7.8, respectively, and for magnetite, they are 6.2 and 6.4 [35]. This agrees with the pzc values shown in the Table 3, in which JST appears to have a pzc of 8.17, and JTT of 6.81. It is important to mention that according to these researchers, at $\mathrm{pH}<\mathrm{pzc}$, the $\mathrm{FeOH}_{2}^{+}$groups predominate over the $\mathrm{FeO}^{-}$groups; therefore, the surface has a net positive charge, which facilitates the absorption of chromium anions that may be present in aqueous solutions mainly as chromate, dichromate, hydrogen chromate, chromic acid, and hydrogen dichromate. The last two species have been detected only in strongly acidic solutions [36]. 
Based on the above, the high protonated adsorbent surface generated a strong electrostatic attraction between chromium species and positively charged JTT, which led to the removal of $53 \%$ of the chromium present in the industrial effluent. One aspect that must be considered is that in a chromium solution, other anions also coexist, such as $\mathrm{Fe}^{2+}$ and $\mathrm{SO}_{4}^{-2}$, which could be competing for the active adsorption sites of iron oxides, and consequently the ability of the adsorbent to remove hexavalent chromium would decrease $[37,38]$.

\subsection{Effect of the Contact Time}

Different tests were carried out to evaluate the chromium removal efficiency using different amounts of JTT. The effects of Cr contact time and its adsorption on JTT were investigated to study the $\mathrm{Cr}$ elimination rate. Figure 4 shows the percentage of $\mathrm{Cr}$ elimination for an initial concentration of $200 \mathrm{mg} / \mathrm{L}$ of $\mathrm{Cr}$ at $\mathrm{pH} 3$.

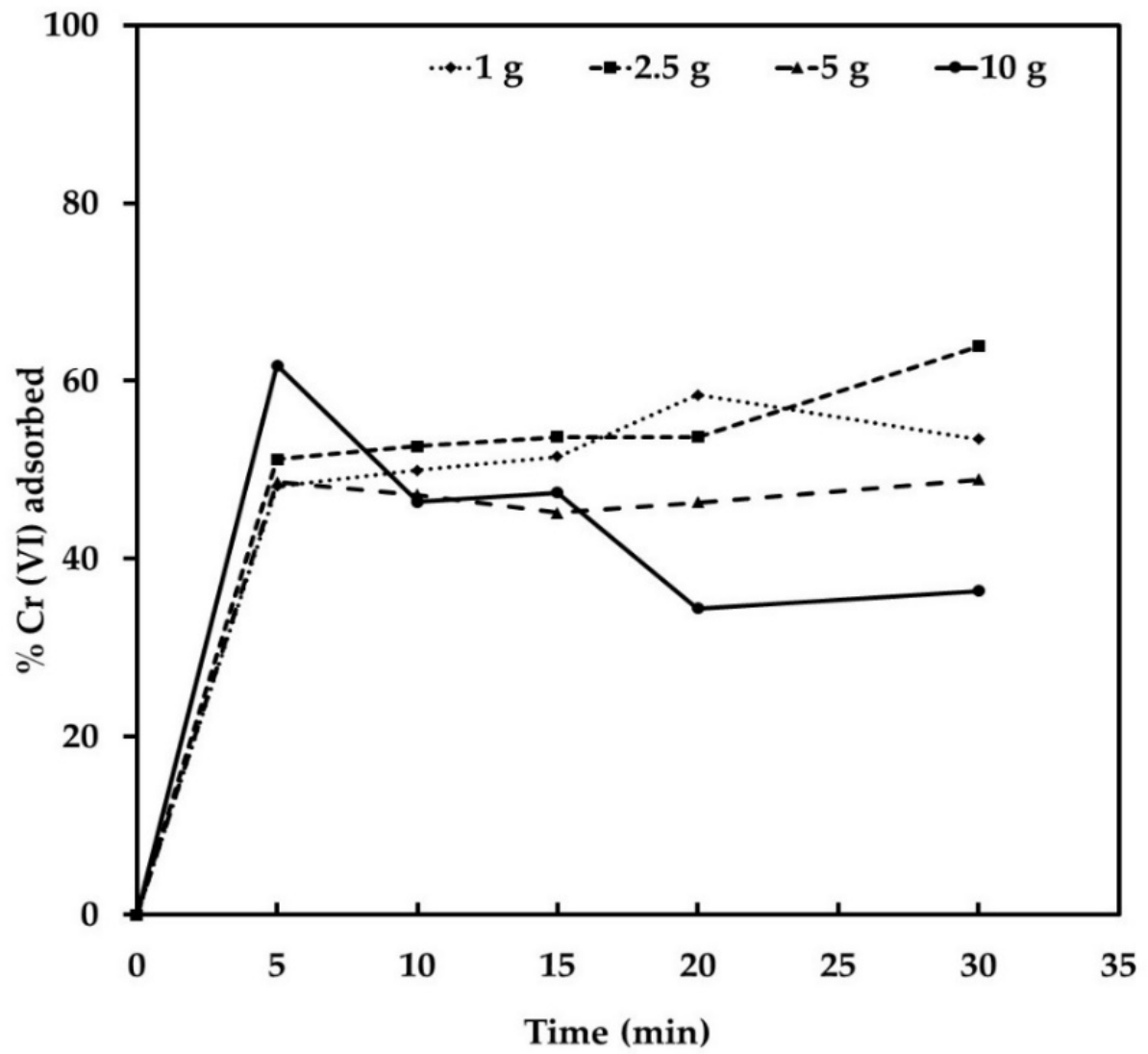

Figure 4. Effect of contact time on the adsorption of $\mathrm{Cr}$ (VI) from industrial wastewater using JTT; temperature $25^{\circ} \mathrm{C}$ and $\mathrm{pH} 3$.

It is evident from the Figure 4 that time is an important parameter for the adsorption of $\mathrm{Cr}$ on JTT, since the increase in the percentage of removal was from $0 \%$ to $50 \%$ during the first $5 \mathrm{~min}$ of contact. The rate of $\mathrm{Cr}$ removal using JTT increased rapidly up to $5 \mathrm{~min}$. A further increase in contact time had a negligible effect on the rate of $\mathrm{Cr}$ adsorption. The nature of the adsorbent and the presence of available adsorption sites affected the rate of $\mathrm{Cr}$ adsorption. The mechanism of transfer from a solute state to a solid one includes diffusion through the fluid film around the adsorbent particles and diffusion through the pores to the internal adsorption sites. In the initial stages of $\mathrm{Cr}$ (VI) adsorption, the concentration gradient between the film and the available pore sites is large, and therefore the rate of $\mathrm{Cr}$ (VI) adsorption is high. The adsorption rate decreases in the later stages of Cr (VI) adsorption, probably due to the slow pore diffusion of solute ions into the bulk of the adsorbent. The rapid adsorption of chromium by iron oxides can be attributed to external 
surface adsorption; chromium access to active adsorption sites is easy, resulting in rapid chromium uptake.

On the other hand, it is important to mention that during the experiments, it was observed that as the dose of the adsorbent increased, the iron in the solution increased proportionally. When $2.5 \mathrm{~g}$ of JTT was used, we found that the iron concentration in the solution increased from $25 \mathrm{mg} / \mathrm{L}$ to $60 \mathrm{mg} / \mathrm{L}$. According to the following equations, the iron oxides present in JTT, in an acidic medium, can dissolve to $\mathrm{Fe}^{2+}$.

$$
\begin{array}{ll}
2 \mathrm{e}^{-}+\mathrm{Fe}_{2} \mathrm{O}_{3}+6 \mathrm{H}^{+}=2 \mathrm{Fe}^{2+}+3 \mathrm{H}_{2} \mathrm{O} & \Delta \mathrm{G}=-36.70 \mathrm{kcal} \\
2 \mathrm{e}^{-}+\mathrm{Fe}_{3} \mathrm{O}_{4}+8 \mathrm{H}^{+}=2 \mathrm{Fe}^{2+}+4 \mathrm{H}_{2} \mathrm{O} & \Delta \mathrm{G}=-49.81 \mathrm{kcal} \\
2 \mathrm{e}^{-}+\mathrm{ZnFe}_{2} \mathrm{O}_{4}+8 \mathrm{H}^{+}=2 \mathrm{Fe}^{2+}+\mathrm{Zn}^{2+}+4 \mathrm{H}_{2} \mathrm{O} & \Delta \mathrm{G}=-49.81 \mathrm{kcal}
\end{array}
$$

Some researchers reported that $\mathrm{Fe}^{2+}$ acts as a reducer of $\mathrm{Cr}$ (VI) [39]; therefore, it could be inferred that $\mathrm{Cr}(\mathrm{VI})$ could be reduced by dissolved iron in the solution, which would inhibit its adsorption on JTT, as shown in the following equation:

$$
3 \mathrm{Fe}^{2+}+\mathrm{HCrO}_{4}^{-}+7 \mathrm{H}^{+}=3 \mathrm{Fe}^{3+}+\mathrm{Cr}^{3+}+4 \mathrm{H}_{2} \mathrm{O} \quad \Delta \mathrm{G}=-49.81 \mathrm{kcal}
$$

\subsection{Adsorption Isotherm Analysis}

Various studies of metal adsorption have evaluated the models of Langmuir, Freundlich, Tempkin, and Dubinin-Radushkevich describing the adsorption process [40,41].

The mentioned models were used to fit the experimental adsorption data of $\mathrm{Cr}$ (VI) removal from industrial wastewater using JTT. Figure 5 shows the adsorption isotherms of the evaluated models.

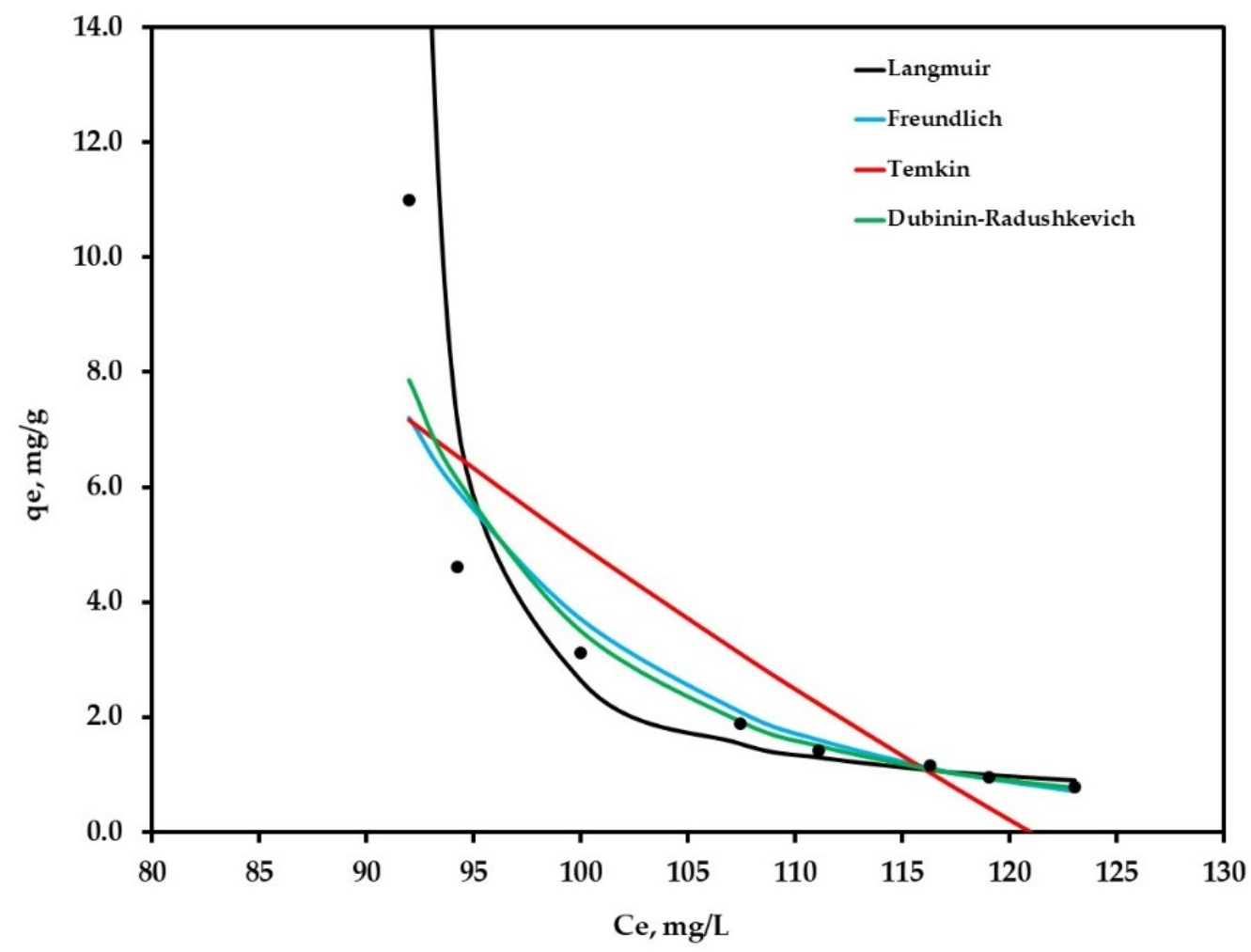

Figure 5. Plot of equilibrium experimental data and calculated equilibrium data using different isotherm models for the adsorption of $\mathrm{Cr}(\mathrm{VI})$ on JTT, with an initial $\mathrm{Cr}(\mathrm{VI})$ concentration of $200 \mathrm{mg} / \mathrm{L}$, temperature $25^{\circ} \mathrm{C}$, initial $\mathrm{pH} 3$.

According to Figure 5 and Table 4, Dubinin isotherm was the model that best fit the experimental data, showing $\mathrm{r}^{2}=0.962$. Dabrowski mentioned in his study that the 
Dubinin-Radushkevich equation with its numerous modifications is very important to describe the characteristics of the adsorption methods of most industries. Generally, the adsorbents have a complex and well-developed porous structure, where micropores play the most important role during adsorption [42]. If the data fitted this model, it would indicate that JTT might be a microporous adsorbent.

Table 4 summarizes the results obtained from fitting the experimental data to the adsorption models.

Table 4. Cr (VI) adsorption isotherm parameters for the JTT sample.

\begin{tabular}{cccc}
\hline Isotherm Model & Parameter & $\mathbf{K}$ & $\mathbf{r}^{\mathbf{2}}$ \\
\hline \multirow{2}{*}{ Freundlich } & $\mathrm{n}$ & -0.125 & 0.944 \\
& $\mathrm{k}$ & $2.01 \times 10^{-3}$ & \\
Langmuir & $\mathrm{qm}$ & 0.233 & 0.949 \\
& $\mathrm{~K}$ & -0.011 & \\
\hline \multirow{2}{*}{ Tempkin } & $\mathrm{R}_{\mathrm{L}}$ & 0.514 & 0.688 \\
& $\mathrm{~A}$ & $2.77 \times 10^{-5}$ & \\
\hline \multirow{2}{*}{ Dubinin-Radushkevich } & $\mathrm{bt}$ & -94.58 & 0.962 \\
& $\mathrm{~K}$ & -0.007 & \\
\hline
\end{tabular}

On the other hand, the data reasonably fitted the Langmuir model. This model is based on the assumption that adsorption occurs at specific homogeneous sites within the adsorbent, and once a chromate molecule occupies a site, no further adsorption can occur there. This coincides with what is shown in Figure 4, where chromium adsorption took place in the first $5 \mathrm{~min}$ and subsequently reached equilibrium. Therefore, it was inferred that the process inhibition at 5 min might be due to the formation of a layer on the particles.

\subsection{Kinetic Study of the Cr (VI) Removal Process}

A kinetic study of $\mathrm{Cr}(\mathrm{VI})$ removal was conducted at atmospheric pressure, $25^{\circ} \mathrm{C}$, and using an aqueous solution with an initial $\mathrm{Cr}$ (VI) concentration of $200 \mathrm{mg} / \mathrm{L}$. Kinetic models of pseudo-first-order, pseudo-second-order, and intraparticle diffusion were studied in the present work $[43,44]$.

Fitting the experimental data with the kinetic models previously described and corresponding kinetics parameters yielded the results summarized in Table 5 and Figure 6.

Table 5. Kinetic parameters values determined by fitting the experimental data of $\mathrm{Cr}(\mathrm{VI})$ removal under dynamic conditions for JTT.

\begin{tabular}{ccccc}
\hline Kinetic Model & & Parameters & $\mathbf{r}^{2}$ \\
\hline \multirow{2}{*}{ Pseudo-1st order } & $\mathrm{Qe}$ & $\mathrm{K}_{\mathrm{ad}}$ & & 0.51 \\
& 271.89 & 0.02 & $\mathrm{~h}$ & 0.98 \\
\multirow{2}{*}{ Pseudo-2nd order } & $\mathrm{Qe}$ & $\mathrm{K}_{2}$ & 2.36 & \\
\hline \multirow{2}{*}{ Intraparticle diffusion } & 12.15 & 0.01 & & 0.92 \\
& $\mathrm{BL}$ effect & $\mathrm{K}_{\mathrm{id}}$ & \\
\hline
\end{tabular}

As can be seen in Table 5 and Figure 6, the kinetic model that best fit the experimental data was the pseudo-second-order model $\left(\mathrm{r}^{2}=0.98\right)$, which describes the transient $\mathrm{Cr}$ (VI) removal process. These results support the hypothesis mentioned above that $\mathrm{Cr}$ (VI) removal occurred through ion exchange, which would facilitate the regeneration of the adsorbent.

The fast adsorption of Cr (VI) observed at short contact times may be attributed to surface reactions between the positively charged iron groups and the chromium anions. 

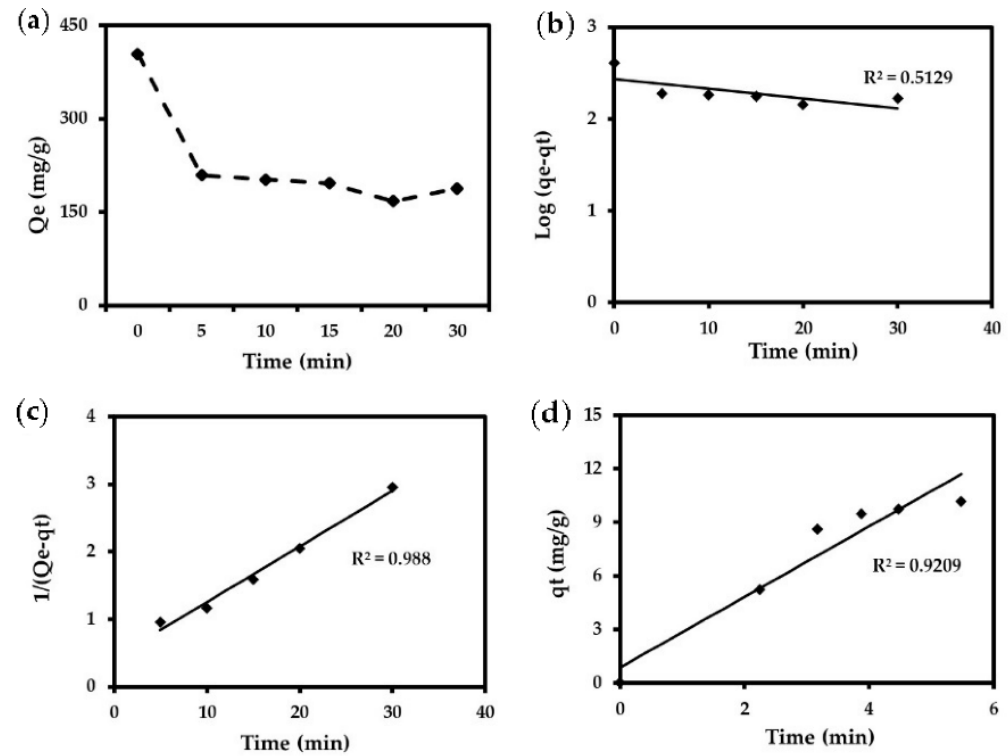

Figure 6. (a) Removal of $\mathrm{Cr}(\mathrm{VI})$ under the following conditions: $1 \mathrm{~g}$ of JTT, $\mathrm{Cr}(\mathrm{VI})=200 \mathrm{mg} / \mathrm{L}$, $\mathrm{T}=25{ }^{\circ} \mathrm{C}$. Evaluation of kinetic models using: (b) Pseudo-first-order kinetic model, (c) Pseudosecond-order kinetic model, (d) Intraparticle diffusion model.

\section{Conclusions}

In the present work, it was decided to evaluate the use of jarosite with and without heat treatment as a low-cost adsorbent for the removal of hexavalent chromium contained in a solution from the chrome plating industry. It is worth mentioning that there is not much information in the literature on the use of jarosites as adsorbents.

When using jarosite without heat treatment (JST), the maximum removal of $\mathrm{Cr}$ (VI) was 34\%. Later, jarosite was previously thermally modified at $600{ }^{\circ} \mathrm{C}$ (JTT), obtaining a material composed of the iron oxides $\mathrm{Fe}_{2} \mathrm{O}_{3}(47 \%), \mathrm{Fe}_{3} \mathrm{O}_{4}(20 \%), \mathrm{ZnFe}_{2} \mathrm{O}_{4}(23 \%)$, and it was possible to increase the removal of hexavalent chromium to $53 \%$; this percentage corresponds to a chromium adsorption capacity of $10.99 \mathrm{mg} / \mathrm{g}$.

Several models of adsorption isotherms were evaluated, i.e., Langmuir, Freundlich, Tempkin, and Dubinin-Radushkevich. This last model was the one that best fits to the experimental data $\left(r^{2}=0.9962\right)$. On the other hand, it was found that the pseudo-secondorder kinetic model was the one that best fit the test data.

It was found that part of the iron in the iron oxides of the JTT adsorbent dissolves during the process, and this could reduce hexavalent chromium to trivalent chromium, which does not represent a risk to health and the environment like $\mathrm{Cr}$ (VI). Therefore, this could explain the fact that after 5 min of testing, the equilibrium was reached in the process, since trivalent chromium, which is a cation, has no affinity to the surface of the adsorbent.

In future experiments, we plan to study more treatment options for jarosites, the regeneration of used jarosites to determine the adsorption-desorption cycles, as well as the development of new products based on spent adsorbent material, such as pigments, magnets, and construction materials, which could be good options because heat-treated jarosite contains iron oxides.

Author Contributions: Conceptualization, N.G.P.-R. and I.A.G.; Investigation, N.G.P.-R., F.R.C.P., and A.M.-L.; methodology, N.G.P.-R.; formal analysis, F.R.C.-P., I.A.G., M.d.J.S.-A., and G.G.; Resources, N.G.P.-R., F.R.C.-P., I.A.G., and M.d.J.S.-A.; Visualization, A.M.-L., G.B., and G.G.; supervision, F.R.C.-P.; project administration, N.G.P.-R.; funding acquisition, N.G.P.-R.; writing-original draft preparation, N.G.P.-R.; writing-review and editing, F.R.C.-P., M.d.J.S.-A., and G.B. All authors have read and agreed to the published version of the manuscript. 
Funding: The financing for the realization of this work was granted by the Government of the State of Coahuila and the COECYT through the "Fund Destined to Promote the Development of Science and Technology in the State of Coahuila, the funding number was COAH-2021-C15-C043.

Institutional Review Board Statement: Not applicable.

Informed Consent Statement: Not applicable.

Data Availability Statement: Data are available based on reasonable request.

Acknowledgments: The authors thank Coecyt Coahuila for the financing provided through the FONCYT program to carry out this project.

Conflicts of Interest: The authors declare no conflict of interest.

\section{References}

1. Reyes, I.; Patiño, F.; Flores, M.; Pandiyan, T.; Cruz, R.; Gutiérrez, E.; Reyes, M.; Flores, V. Dissolution rates of jarosite-type compounds in $\mathrm{H}_{2} \mathrm{SO}_{4}$ medium: A kinetic analysis and its importance on the recovery of metal values from hydrometallurgical wastes. Hydrometallurgy 2017, 167, 16-29. [CrossRef]

2. Calla, D.; Nava, F.; Fuentes, J. Acid decomposition and thiourea leaching of silver from hazardous jarosite residues: Effect of some cations on the stability of the thiourea system. J. Hazard. Mater. 2016, 317, 440-448. [CrossRef]

3. Arslan, C. Thermochemical Review of Jarosite and Goethite Stability Regions at 25 and $95{ }^{\circ} \mathrm{C}$. Turkish J. Eng. Environ. Sci. 2003, 27, $45-52$.

4. Matinde, E.; Simate, G.S.; Ndlovu, S. Mining and metallurgical wastes: A review of recycling and re-use practices. J. S. Afr. Inst. Min. Metall. 2018, 118, 825-844. [CrossRef]

5. Hussein, I.; Shafy, A.; Mansour, S.M. Solid waste issue: Sources, composition, disposal, recycling, and Valorization. Egypt. J. Pet. 2018, 27, 1275-1290.

6. Xu, C.; Xie, Q.; Xu, F.; Zhou, Y.; Hanlin, W.; Chen, T.; Peng, S. Preparation of Monoclinic Pyrrhotite by Thermal Decomposition of Jarosite Residues and Its Heavy Metal Removal Performance. Minerals 2021, 11, 267. [CrossRef]

7. Yu, A.; Wong, I.; Wu, Z.; Poon, C.S. Strategies for EffectiveWaste Reduction and Management of Building Construction Projects in Highly Urbanized Cities-A Case Study of Hong Kong. Buildings 2021, 11, 214. [CrossRef]

8. Tang, L.; Tang, C.; Xiao, J.; Zeng, P.; Tang, M. A cleaner process for valuable metals recovery from hydrometallurgical zinc residue. J. Clean. Prod. 2018, 261, 764-773. [CrossRef]

9. Picazo, N.G.; Carrillo, F.R.; Martínez, A.; Soria, M.; Almaguer, I. S ${ }^{\circ}$ and jarosite behavior during recovery of values from the direct leaching residue of sphalerite using cyanide and glycine. J. Min. Metall. Sect. B 2021, 57, 349-358. [CrossRef]

10. Labib, S.; Abdelaal, S.; Abdelhady, A.; Elmaghraby, E. Preparation and characterization of jarosite nanorods synthesized by microwave hydrothermal method. Mater. Chem. Phys. 2020, 256, 20A2455118. [CrossRef]

11. Dutrizac, J.E. The effect of seeding on the rate of precipitation of ammonium jarosite and sodium jarosite. Hydrometallurgy 1996, 42, 293-312. [CrossRef]

12. Kostomitsopoulou, A.; Kouzelib, K.; Facorellisc, Y. Colourful earth: Iron-containing pigments from the Hellenistic pigment production site of the ancient agora of Kos (Greece). J. Archaeol. Sci. 2019, 26, 101843. [CrossRef]

13. Mehra, P.; Kumar, S.; Thomas, B.S.; Gupta, R. Analysis on the hazardous jarosite added concrete. Constr. Build. Mater. 2018, 191, 53-259. [CrossRef]

14. Xiaoa, D.; Fangb, C.; Zhouc, J.; Loud, X.; Xiaoe, J.; Liuf, J. Biogenic jarosite: A friendly adsorbent for the removal of chromate from aqueous solution. Appl. Mech. Mater. 2015, 737, 533-536. [CrossRef]

15. Bhatti, M.; Reddy, A.; Thukral, A. Electrocoagulation removal of $\mathrm{Cr}(\mathrm{VI})$ from simulated wastewater using response surface methodology. J. Hazard. Mater. 2009, 172, 839-846. [CrossRef] [PubMed]

16. Jadidi, M.; Esfahany, M. Adsorption and Desorption Processes of Chromium Ions Using Magnetic Iron Oxide Nanoparticles and Their Relevant Mechanism. Iran. J. Chem. Chem. Eng. 2017, 14, 31-40.

17. Tezcan, U.; Eroglu, S.; Ozel, E. The treatment of chromium containing wastewater using electrocoagulation and the production of ceramic pigments from the resulting sludge. J. Environ. Manag. 2017, 200, 196-203. [CrossRef] [PubMed]

18. Bao, Y.; Huang, J.; Cagnetta, G.; Yu, G. Removal of Fe-53B as PFOS alternative in chrome plating wastewater by UV/Sulfite reduction. Water Res. 2019, 163, 114907. [CrossRef]

19. Peng, H.; Leng, Y.; Cheng, Q.; Shang, Q.; Shu, J.; Guo, J. Efficient Removal of Hexavalent Chromium from Wastewater with Electro-Reduction. Processes 2019, 7, 41. [CrossRef]

20. Hsu, N.; Wang, S.; Liao, Y.; Huang, S.; Tzou, Y.; Huang, Y. Removal of hexavalent chromium from acidic aqueous solutions using rice straw-derived carbon. J. Hazard. Mater. 2009, 171, 1066-1070. [CrossRef]

21. Mitra, A.; Mehran, H.; Arezoo, T.; Mahmoud, K.; Majid, A. Optimization of factors affecting hexavalent chromium removal from simulated electroplating wastewater by synthesized magnetite nanoparticles. Environ. Monit. Assess. 2015, $187,4165$.

22. Hu, J.; Lo, I.; Chen, G. Removal of Cr(VI) by magnetite nanoparticle. Water Sci. Technol. 2018, 50, 139-146. [CrossRef] 
23. Pan, Z.; Zhu, X.; Satpathy, A.; Li, W. Cr(VI) Adsorption on Engineered Iron Oxide Nanoparticles: Exploring Complexation Processes and Water Chemistry. Environ. Sci. Technol. 2019, 53, 11913-11921. [CrossRef] [PubMed]

24. Achla, K. Adsorption phenomenon and its application in removal of lead from waste water: A review. Int. J. Hydrog. 2017, 1, $38-47$.

25. Carrillo, F.; Soria, M.; Sanchez, M.; Martínez, A.; Picazo, N. Adsorption of chromium from steel plating wastewater using blast furnace dust. Rev. Int. Contam. Ambient. 2017, 33, 591-603. [CrossRef]

26. Kunda, W.; Veltman, H. Decomposition of jarosite. Metall. Trans. B 1979, 10B, 439-446. [CrossRef]

27. Frost, R.; Wills, R.; Weier, M.; Martens, W. Thermal decomposition of synthetic argentojarosite-Implications for silver production in medieval times. Thermochim. Acta 2005, 437, 30-33. [CrossRef]

28. Ristić, M.; Musić, S.; Orehovec, Z. Thermal decomposition of synthetic ammonium jarosite. J. Mol. Struct. 2005, 744, 295-300. [CrossRef]

29. Kaisani, H.; Kasongo, K.; Naude, N.; Katabua, J. Enhanced leachability of gold and silver in cyanide media: Effect of alkaline pre-treatment of jarosite minerals. Min. Eng. 2008, 21, 1075-1082. [CrossRef]

30. Patiño, F.; Reyes, I.; Rivera, I.; Reyes, M.; Hernández, J.; Pérez, M. Decomposition Kinetics of Argentian Lead Jarosite in NaOH Media. J. Mex. Chem. Soc. 2011, 55, 208-213.

31. González, A.; Nava, F.; Fuentes, J.; Uribe, A. Hydrothermal decomposition of industrial jarosite in alkaline media: The rate determining step pf the process kinetics. J. Min. Metall. Sect. B 2016, 52, 135-142. [CrossRef]

32. Arroyo, M.G.; Pérez, V.; Montañés, M.T.; García, J.; Guiñón, J. Effect of pH and chloride concentration on the removal of hexavalent chromium in a batch electrocoagulation reactor. J. Hazard. Mater. 2009, 169, 1127-1133. [CrossRef]

33. Smith, E.; Ghiassi, K. Chromate Removal by an Iron Sorbent: Mechanism and Modeling. Water Environ. Res. 2006, 78, 84-93. [CrossRef] [PubMed]

34. Petrova, T.; Fachikov, L.; Hristov, J. The Magnetite as Adsorbent for Some Hazardous Species from Aqueous Solutions: A Review. Int. Rev. Chem. Eng. 2011, 3, 134-152.

35. Cornell, R.M.; Schwertmann, U. The Iron Oxides: Structure, Properties, Reactions, Occurrence and Uses; Wiley-VCH: Weinheim, Germany, 2003.

36. Rakhunde, R.; Deshpande, L.; Juneja, H. Chemical Speciation of Chromium in Water: A Review. Environ. Sci. Technol. 2011, 42, 776-810. [CrossRef]

37. Gupta, S.; Babu, B.V. Removal of toxic metal $\mathrm{Cr}(\mathrm{VI})$ from aqueous solutions using sawdust as adsorbent: Equilibrium, kinetics and regeneration studies. Chem. Eng. J. 2009, 150, 352-365. [CrossRef]

38. Pakade, V.; Tavengwab, N.; Madikizelac, L. Recent advances in hexavalent chromium removal from aqueous solutions by adsorptive methods. RSC Adv. 2019, 9, 26142-26164. [CrossRef]

39. Kiser, J.; Manning, B. Reduction and immobilization of chromium(VI) by iron(II)-treated faujasite. J. Hazard. Mater. 2010, 174, 167-174. [CrossRef]

40. Piccin, J.S.; Dotto, G.; Pinto, A. Adsorption isotherms and Thermochemical data of fd\&c Red N ${ }^{\circ} 40$ Binding by chitosan. Braz. J. Chem. Eng. 2011, 28, 295-304.

41. Soria, M.; Martínez, A.; Sánchez, M.; Carrillo, F.R.; Toro, N.; Narvaez, V. Removal of Pb(II) from aqueous solutions by using steelmaking industry wastes: Effect of blast furnace dust's chemical composition. Arab. J. Chem. 2021, 14, 103061. [CrossRef]

42. Dabrowski, A. Adsorption-Its development and application for practical purposes. Stud. Surf. Sci. Catal. 1998, $160,3-68$.

43. Ezzati, R. Derivation of Pseudo-First-Order, Pseudo-Second-Order and Modified Pseudo-First-Order rate equations from Langmuir and Freundlich isotherms for adsorption. Chem. Eng. J. 2020, 329, 123705. [CrossRef]

44. Simonin, J.; Bouté, J. Intraparticle diffusion-adsorption model to describe liquid/solid adsorption kinetics. Rev. Mex. Ing. Química 2016, 15, 161-173. 